\title{
STRUCTURAL CONTROLS ON THE TETON NORMAL FAULT, TETON COUNTY, WYOMING
}

David R. Lageson

Department of Earth Sciences

Montana State University

Bozeman

\section{Objectives}

The Teton normal fault crops out along the eastern base of the Teton Range and relative motion across this fault has both uplifted the Teton Range and down-dropped Jackson Hole. On surface maps the normal fault appears to lie across older Laramide faults at a high angle, thus suggesting that previous structures had little to do with the position of the normal fault. Therefore, this field study was undertaken to test the following question: have preexisting Laramide or basement structures affected the position and/or geometry of the Teton normal fault? This question becomes important when considering the potential for contemporary earthquakes along the Teton normal fault and understanding the geologic environment of these earthquakes.

\section{Methods}

Three possibilities were tested to determine if they have affected the position and/or geometry of the Teton normal fault. First, the geometrical relationship of the Teton normal fault to the older, Laramide Cache Creek thrust (which bounds the SW flank of the Gros Ventre Range) was studied in the field and with existing geologic maps and cross sections. Second, the attitude and character of Precambrian shear zones with the Teton Range was studied to see if such zones could have been reactivated by the Teton normal fault. Third, the attitude of metamorphic foliation proximal to the Teton normal fault was measured to see if this fabric could provide a favorable slip zone for the Teton normal fault.

Field work was conducted over 3 weeks during the 1987 field season. The UW-NPS Research Center was used as a base during the summer and fall of 1987 by "commuting" from Montana State University.

\section{Results}

Preliminary results suggest that the Teton normal fault has exploited a portion of the older Cache Creek thrust system. Two large, en echelon, Laramide uplifts dominated the present site of Grand Teton and southern Yellowstone National Parks during early Cenozoic time. The ancestral 
Gros Ventre Range, bound on the SW by the Cache Creek thrust, formed a basement-cored arch across the SW part of the area. To the NE, the Washakie Range, bound along its west flank by the Buffalo Fork thrust, formed the other basement arch. The synclinal trough between these two arches was interrupted by the Basin Creek uplift. The Neogene Teton Range was superimposed over the ancestral Gros Ventre arch at a point where the Cache Creek thrust ramped upsection to the west, forming a "perched basement wedge." The Buck Mountain reverse fault in the core of the Teton Range may be a splay off this ramp. Also, the Forellen fault at the north end of the Tetons is a SW-verging parasitic structure that formed on the $\mathrm{NE}$ flank of the ancestral Gros Ventre arch.

Other evidence for structural controls on the Teton normal fault is at the $\mathrm{NW}$ end of the Wind River Range in the Green River Lakes area, where Richmond (1945) mapped several north-northwest trending basement shear zones in the hanging wall of the Wind River thrust. Mitra and Frost (1981) and Mitra (1984) recognized three generations of shear zones: 1) early Precambrian, characterized by recrystallized, banded, mylonitic rocks; 2) late Precambrian, characterized by retrograde chloriteactinolite assemblages, and weathering to form prominent, linear depressions; and 3)Laramide, characterized by "brittle granulation which took place in the presence of small amounts of fluid, leading to grainsize breakdown, development of slickensides, and the growth of some phengitic mica" (zeolite facies metamorphism). Basement shear zones have also been described in the Teton Range, subparallel to the Teton normal fault. Bradley (1956) described three, east-dipping, reverseslip shear zones northwest of Phelps Lake, one of which occurs near the base of the range. These shear zones are overprinted by brecciation, gouge, iron-oxide stain, and crumpling of adjacent gneissic foliation, indicating reactivation under brittle conditions similar to "type 3" shear zones of Mitra and Frost (1981). Bradley (1956) proposed that the shear zones experienced Precambrian motion and were reactivated during the Laramide orogeny as reverse-slip faults. It is also possible that the Teton normal fault has exploited a set of basement shear zones, similar to those above Phelps Lake.

Lastly, it was determined that the attitude of foliation in metamorphic rocks proximal to the Teton normal fault is favorable for dip-slip displacement. Hundreds of strike-and-dip measurements were made on the foliation of gneissic rocks adjacent to the Teton normal fault. The average strike was found to be north, with dips between 40-50 degrees east. This attitude is almost exactly the same as the strike and dip of the Teton normal fault. Therefore, it is further proposed that the fabric of basement rocks is controlling the attitude and geometry of the Teton normal fault.

\section{Conclusions}

Three factors appear to control the position and geometry of the Teton normal fault. First, the normal fault is controlled by a ramp in the 
underlying Cache Creek thrust fault which dips NE beneath the southern Tetons. Second, Precambrian shear zones in metamorphic rocks proximal to the normal fault may have been reactivated by the Teton normal fault. Third, the strike and dip of metamorphic fabric (foliation) adjacent to the normal fault may have affected its orientation.

\section{Literature Cited}

Bradley, C. C. 1956. The Pre-Cambrian complex of Grand Teton National Park, Wyoming, in, Rocky Mountain thrust belt geology and resources: Joint Wyoming-Montana-Utah Geol. Assoc. Guidebook, p. 769-783.

Mitra, G. and B. R. Frost. 1981. Mechanisms of deformation within Laramide and Precambrian deformation zones in basement rocks of the Wind River Mountains: Contributions to Geology (Univ. WY), $19(2): 161-173$.

Mitra, G. 1984. Brittle to ductile transition due to large strains along the White Rock thrust, Wind River Mountains, Wyoming: J. Struct. Geol., 6:51-61.

Richmond, G. M. 1945. Geology of the northwest end of the Wind River Mountains, Sublette County, Wyoming: U.S. Geol. Survey, Oil and Gas Inv. Prelim. Map 31. 